\title{
Parasite communities of eels Anguilla anguilla in freshwater and marine habitats in Iceland in comparison with other parasite communities of eels in Europe
}

\author{
Árni Kristmundsson and Sigurður Helgason
}

Institute for Experimental Pathology at Keldur, University of Iceland, v/Vesturlandsveg, IS-112 Reykjavik, Iceland

Key words: Anguilla anguilla, eel, parasites, parasite communities, diversity, species richness, comparison, Iceland

\begin{abstract}
Ninety-five eels from one marine and three freshwater localities in Iceland were examined for parasites. Twenty species were found, 12 from marine habitat, 12 from freshwater and 4 species were found in both habitats. These are: Eimeria anguillae, Chilodonella hexasticha, Trichodina fultoni, T. jadranica, Myxidium giardi, Myxobolus kotlani, two Zschokkella spp., Derogenes varicus, Deropristis inflata, Diplostomum sp., Plagioporus angulatus, Podocotyle atomon, Anisakis simplex (larva), Eustrongylides sp. (larva), Hysterothylacium aduncum (larva), Raphidascaris acus (larval and adult stages), Bothriocephalus claviceps, Proteocephalus macrocephalus, and a pseudophyllidean larva. Thirteen of these species are new parasite records from Icelandic waters. The component community of marine eels was characterized by low diversity and a high dominance of a single species. Overall, seven species of helminths were observed, up to five different species occurring in an individual fish. The component community of the freshwater eels was species-poor with low diversity and relatively high dominance of single species. A between-sites difference in the freshwater eels was considerable; only Diplostomum sp. was found at more then one sampling site. Similar to previous studies, there is a total replacement of freshwater macroparasite species by marine ones in saline waters. But unlike research abroad in which species richness decreases with higher salinity, the marine eels in Iceland have considerably higher richness than the freshwater ones. The parasite communities of freshwater eels in Iceland are, in general species-poorer, less diverse and having higher Berger Parker (BP) dominance than other eel communities in Europe. Marine eels have on the other hand comparable species richness, are less diverse and with a high BP dominance.
\end{abstract}

Five species of fishes live in the Icelandic freshwater ecosystem: Atlantic salmon Salmo salar L., brown trout Salmo trutta L., arctic char Salvelinus alpinus (L.), three-spined stickleback Gasterosteus aculeatus L., and eel Anguilla anguilla (L.). According to Albert et al. (2006), about $15 \%$ of the eel population in Iceland are hybrids between $A$. anguilla and the American eel, $A$. rostrata (Lesueur). During the last decades, extensive research on the parasite fauna of the European eel has been carried out in many European countries (e.g. Køie 1988, Kennedy 1997, Kennedy et al. 1997, Borgsteede et al. 1999, Sures et al. 1999, Saraiva et al. 2005). To date, observations on parasites of Icelandic freshwater fishes have been limited; only few papers published, focusing on parasites of salmonids (Stephenson 1940, Brinckmann 1956, Baer 1962, Richter 1981, Richter 1982a, b, c, Malmquist et al. 1986, Frandsen et al. 1989, Kristmundsson and Richter 2002-2003) and threespined sticklebacks (Blair 1973). The present study is the first one made on the parasite fauna of eels in Iceland. This paper presents the composition and diversity characteristics of parasite communities of freshwater and marine eels in Iceland in comparison with other similar studies in Europe.

\section{MATERIALS AND METHODS}

Study area and fish collection. A total number of 95 eels from one marine $(\mathrm{GV})$ and three freshwater localities $(\mathrm{OL}, \mathrm{ST}$,
VV) were examined (Fig. 1). The eels were caught in fyke nets; samples from OL in September 2000 and 2001; from ST in August 1999 and August-September 2000; from VV in June 2000 and October 2001; from GV in June-July 2001. Eel length ranged from 34.0 to $63.5 \mathrm{~cm}$ (median $53.5 \mathrm{~cm}$ ) in OL, from 33.5 to $72.5 \mathrm{~cm}$ (median $59.3 \mathrm{~cm}$ ) in $\mathrm{ST}$, from 33.0 to $71.0 \mathrm{~cm}$ (median $54.3 \mathrm{~cm}$ ) in VV and from 42.0 to $71.0 \mathrm{~cm}$ (median $52.3 \mathrm{~cm}$ ) in GV (Fig. 2).

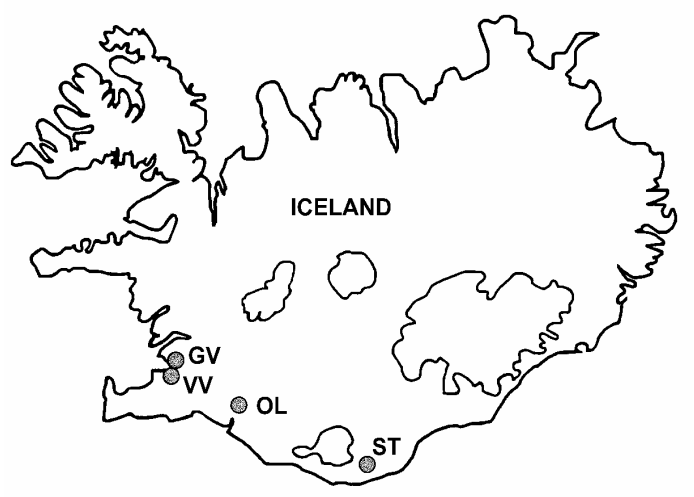

Fig. 1. Sampling sites. GV - Grafarvogur $(\mathrm{n}=20)$, a shallow creek with a salinity of $30-33 \%$; $\mathbf{O L}$ - ditches and tributaries of the glacial river Olfusa $(\mathrm{n}=15)$; $\mathbf{S T}-$ Steinsmyrarfljot $(\mathrm{n}=30)$, a small shallow lake (max depth $<2.5 \mathrm{~m})$; VV - Vifilsstadavatn $(\mathrm{n}=30)$, a small shallow lake (max depth $<2.5$ $\mathrm{m})$. All three freshwater localities harbour brown trout, arctic char and three-spined sticklebacks; OL also harbours salmon. 


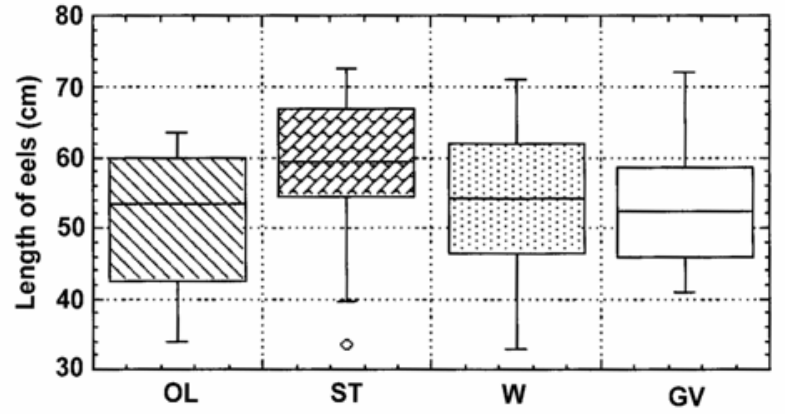

Fig. 2. Length distribution of eels from the localities studied.

The eels were brought alive to the laboratory and either kept alive in aquaria until they were examined (completed within a week of capture), or kept frozen at $-20^{\circ} \mathrm{C}$ for subsequent examination. If examined frozen, the gills were excised and put in $70 \%$ alcohol prior to freezing.

Examination of eels and identification of parasites. The eels were killed with an overdose of phenoxyethanol, and their length and weight was determined. The external surface, fins, nostrils, buccal cavity, each gill arch and excised eyes were examined thoroughly with a stereoscope. Smears from blood and eye tissues and scrapings from the external surface and from slices of two gill arches from each side of a fish were examined for parasites with a compound microscope. The visceral cavity and all major organs (heart, brain, liver, kidney, spleen, gall bladder, urinary bladder, swim-bladder and gonads) were examined thoroughly using both a microscope and a stereoscope. The alimentary tract was removed; the oesophagus, stomach and intestine, each kept separate in Petri dishes, were split longitudinally and scrapings from all parts prepared for a microscopic examination. Finally contents of the stomach and the intestine were searched for intestinal helminths using both microscope and stereoscope. Ciliates of the genera Chilodonella and Trichodina were identified by the use of Klein's silver nitrate technique (Klein 1958). To identify cestode species, proglottids were stained with Schneider's acetocarmine (Ash and Oriel 1987). Final identification to a species and/or genus level, was based on BykhovskayaPavlovskaya et al. (1964), Lom and Dyková (1992), Moravec (1994), Hoffmann (1999) and Buchmann and Bresciani (2001).

Determination of helminth community structure and statistical treatment. Specialists are defined as those parasites that occur and reproduce almost exclusively in eels whereas generalists are those that commonly occur in other families of fishes. Definitions of other ecological terms are according to Bush et al. (1997). Analysis of the parasite community structure was carried out at both component and infracommunity level. The measures of the component community structure adopted were: species richness (total number of species), the Shannon-Wiener (SW) diversity index and its Evenness, Simpson's reciprocal index (SI:1/D) and the BergerParker dominance index (BP). To get comparative figures from several other similar studies, in which different logarithm $\left(\log _{2}\right)$ was used, the diversity indices were recalculated from data given. Additionally, diversity indices and dominance values from data given in a number of publications in which those community characteristics where not analysed were calculated. The measures of the infracommunity structure adopted were: mean number of individuals and species per eel, the maximum number of species per eel, the mean Brillouin's index (BI) (all eels and infected eels only) and the maximum value of the BI. All indices were calculated and defined according to Magurran (1988) using natural logarithm (ln) where appropriate. The Percentage Similarity index (quantitative measure) and the Sörensen's index of similarity (qualitative) (Magurran 1988) were used to measure similarities between localities at the component level. Statistical difference between the Shannon Wiener diversity indices of the localities studied was tested using a modified $t$-test proposed by Hutcheson (1970).

\section{RESULTS}

Composition of the parasite communities Table 1

Four protozoan species were found. Eimeria anguillae Léger et Hollande, 1922 (Sporozoa: Cocccidia) was detected in the intestine of one freshwater and one marine eel. Trichodina jadranica Raabe, 1958 (Ciliophora: Trichodinidae) was frequent on the gills of eels from VV and OL as was Trichodina fultoni Davis, 1947 (Ciliophora: Trichodinidae) on the skin and gills of eels from OL and ST. Chilodonella hexasticha (Kiernik, 1909) (Ciliophora: Chilodonellidae), also on gills and skin, was found only on eels from OL. Four myxozoan species, Myxidium giardi Cépède, 1906 (Bivalvulida: Myxidiidae), Myxobolus kotlani Molnár, Lom et Malik, 1986 (Bivalvulida: Myxobolidae) and two Zschokkella spp. (Bivalvulida: Myxidiidae), were observed from both freshwater and marine localities, the three latter species only on rare occasions (prevalence: 3.3 to $6.6 \%$ ) but $M$. giardi in high prevalence (30.0 to $93.3 \%$ ) at all sampling sites. Myxidium giardi most heavily infected the gills, but kidneys and various other organs were also frequently infected. Myxobolus kotlani was detected from fins and two species of Zschokkella, one in fins and the other one in the stomach mucosa.

Twelve helminth species were found; seven in the marine eels and five in freshwater ones. The marine eels had only marine species and the freshwater eels only freshwater species. Diplostomum sp. (metacercariae) (Strigeoidea: Diplostomatidae) was found in eels from all the freshwater sites and was the most prevalent helminth species at ST $(66.6 \%)$ and OL (20.0\%). An encapsulated larval stage of the nematode Eustrongylides sp. (Dioctophymatiodea: Dioctophymatidae) was found only in the stomach wall of eels from VV $(13.3 \%)$. One specimen of a third-stage larva of Anisakis simplex (Rudolphi, 1809) (Ascaridida: Anisakidae) was found in the visceral cavity of one marine eel. Nine species of gastrointestinal helminths were present in the eels: four species of digeneans, Deropristis inflata (Molin, 1859) (Allocreadiodea: Deropristiidae), Derogenes varicus (Müller, 1784) (Hemiuroidea: Derogenidae), Podocotyle atomon (Rudolphi, 1802) (Allocreadiodea: Opecoelidae) and Plagioporus angulatus Du- 
Table 1. Infected organs, prevalence (P), mean intensity and intensity range of the parasite species found at the localities studied.

\begin{tabular}{|c|c|c|c|c|c|c|c|c|c|c|c|c|c|}
\hline $\begin{array}{l}\text { Locality } \\
\text { (Salinity) }\end{array}$ & \multicolumn{4}{|c|}{$\begin{array}{c}\mathrm{OL} \\
(0 \%)\end{array}$} & \multicolumn{3}{|c|}{$\begin{array}{c}\mathrm{ST} \\
(0 \%)\end{array}$} & \multicolumn{3}{|c|}{$\begin{array}{l}\text { VV } \\
(0 \% \text { ) }\end{array}$} & \multicolumn{3}{|c|}{$\begin{array}{c}\text { GV } \\
(30-33 \%)\end{array}$} \\
\hline Number of eels examined & \multicolumn{4}{|c|}{15} & \multicolumn{3}{|c|}{30} & \multicolumn{3}{|c|}{30} & \multicolumn{3}{|c|}{20} \\
\hline & & & \multicolumn{2}{|c|}{ Intensity } & & \multicolumn{2}{|c|}{ Intensity } & \multicolumn{3}{|c|}{ Intensity } & \multicolumn{3}{|c|}{ Intensity } \\
\hline PROTOZOA & $\begin{array}{c}\text { Infected } \\
\text { organs }\end{array}$ & $\mathrm{P}$ & Range & $\begin{array}{l}\text { Mean } \\
\pm \text { SD }\end{array}$ & $\mathrm{P}$ & Range & $\begin{array}{l}\text { Mean } \\
\pm \text { SD }\end{array}$ & $\mathrm{P}$ & Range & $\begin{array}{l}\text { Mean } \\
\pm \text { SD }\end{array}$ & $\mathrm{P}$ & Range & $\begin{array}{l}\text { Mean } \\
\pm \text { SD }\end{array}$ \\
\hline Eimeria anguillae* & I & $6.6^{1}$ & ND & ND & - & - & - & - & - & - & $5.0^{1}$ & ND & ND \\
\hline Chilodonella hexasticha* & $\mathrm{G} / \mathrm{S}$ & X & ND & ND & - & - & - & - & - & - & $\begin{array}{ll}.0 \\
-\end{array}$ & - & - \\
\hline Trichodina fultoni* & $\mathrm{G} / \mathrm{S}$ & $\mathrm{X}$ & ND & ND & $\mathrm{X}$ & ND & ND & - & - & - & - & - & - \\
\hline Trichodina jadranica* & $\mathrm{G}$ & $\mathrm{X}$ & ND & ND & - & - & - & $\mathrm{X}$ & ND & ND & - & - & - \\
\hline \multicolumn{14}{|l|}{ METAZOA } \\
\hline Myxidium giardi* & $\mathrm{G} / \mathrm{K} / \mathrm{VO}$ & 93.3 & ND & ND & 33.3 & ND & ND & 30.0 & ND & ND & 70.0 & ND & ND \\
\hline Zschokkella sp.-1* & $\mathrm{F}$ & $6.6^{1}$ & ND & ND & 6.6 & ND & ND & - & - & - & - & - & - \\
\hline Zschokkella sp.-2* & SW & - & - & - & - & - & - & 6.6 & ND & ND & $5.0^{1}$ & ND & ND \\
\hline Myxobolus kotlani* & $\mathrm{F}$ & $6.6^{1}$ & ND & ND & $3.3^{1}$ & ND & ND & - & - & - & $5.0^{1}$ & ND & ND \\
\hline Diplostomum sp. & $\mathrm{E}$ & 20.0 & $1-6$ & $3.6 \pm 2.5$ & 66.6 & $1-13$ & $3.4 \pm 2.8$ & 20.0 & $2-14$ & $6.0 \pm 5.9$ & - & - & - \\
\hline Derogenes varicus & ST & - & - & - & - & - & - & - & - & - & 45.0 & $1-6$ & $1.7 \pm 1.6$ \\
\hline Deropristis inflata* & I & - & - & - & - & - & - & - & - & - & 85.0 & $2-379$ & $104.6 \pm 123.7$ \\
\hline Podocotyle atomon & I & - & - & - & - & - & - & - & - & - & 20.0 & $1-3$ & $1.7 \pm 0.9$ \\
\hline Plagioporus angulatus* & I & - & - & - & - & - & - & - & - & - & 15.0 & $1-6$ & $3.7 \pm 2.5$ \\
\hline Anisakis simplex & $\mathrm{VC}$ & - & - & - & - & - & - & - & - & - & $5.0^{1}$ & 1 & 1 \\
\hline Hysterothylacium aduncum & I & - & - & - & - & - & - & - & - & - & 10.0 & $1-2$ & $1.7 \pm 0.5$ \\
\hline Raphidascaris acus* & I & - & - & - & 43.3 & $1-18$ & $4.0 \pm 5,0$ & - & - & - & - & - & - \\
\hline Eustrongylides sp.* & SW & - & - & - & - & - & - & 13.3 & $1-2$ & $1.5 \pm 0.5$ & - & - & - \\
\hline Proteocephalus macrocephalus* & I & - & - & - & 16.6 & $1-2$ & $1.3 \pm 0.5$ & - & - & - & - & - & - \\
\hline Bothriocephalus claviceps* & I & - & - & - & - & - & - & 26.6 & $1-25$ & $5.7 \pm 7.9$ & - & - & - \\
\hline pseudophyllidean larva & I/IW & - & - & - & - & - & - & - & - & - & 10.0 & 2 & $2.0 \pm 0.0$ \\
\hline
\end{tabular}

*New parasite records for Iceland.; G - gills; K - kidney; F - fin; I - intestine; S - skin; E - eye; VC - visceral cavity; IW - intestinal wall; ST - stomach; SW - stomach wall; $\mathrm{VO}$ - various organs; ${ }^{1}$ only one eel infected; $\mathrm{X}$ - species found but prevalence not determined; ND - number of parasites not determined. 
jardin, 1845 (Fasciolata: Opecoelidae); two nematode species, Raphidascaris acus (Bloch, 1779) (Ascaridida: Anisakidae) and Hysterothylacium aduncum (Rudolphi, 1802) (larva) (Ascaridida: Anisakidae); and three cestode species, Bothriocephalus claviceps (Goeze, 1782) (Pseudophyllidea: Bothriocephalidae), Proteocephalus macrocephalus (Creplin, 1825) (Proteocephaloidea: Proteocephalidae), and a pseudophyllidean larva. In marine eels, the eel-specific parasite $D$. inflata was by far the most prevalent species $(85.0 \%)$. In freshwater, the nematode $R$. acus was the most prevalent intestinal helminth at locality ST $(43.3 \%)$ and the cestode B. claviceps at locality VV (26.6\%). No intestinal helminths were detected at locality OL.

\section{Similarity between communities}

Tables 2, 3

The only macroparasite species any two sampling sites had in common was Diplostomum sp. On a qualitative basis (Sörensen's index), the levels of total component similarity of macroparasite communities between the three freshwater sites ranged from 0.33 to 0.50 . It was the same for OL-ST and OL-VV (0.5) but lower for ST-VV (0.33). On a quantitative basis (Percentage similarity index) the OL-ST values were $54 \%$ but $41 \%$ for OL-VV and VV-ST. The eels from the marine site GV and those from the three freshwater sites harboured entirely different helminth species. None of the localities had any intestinal helminth species in common; therefore their intestinal helminth communities were completely dissimilar. The Sörensen's index between the total microparasite component communities was generally rather high. It was highest for GV-ST (0.75) but lowest for VV-ST (0.29).

\section{Component community structure}

Tables 4, 5

The total macroparasite community of eels from the marine locality $\mathrm{GV}$ was richer (7 species) than the ones from all freshwater localities (1-3 species). The diversity was, however, significantly lower than from the freshwater sampling sites ST and VV, which had very similar diversity values and the evenness was considerably lower. The GV's low diversity reflects its high Berger-Parker dominance value (0.98), the eel specific parasite Deropristis inflata being the dominant species. Eels from the sampling site OL had the lowest value in richness, diversity and evenness, harbouring only one helminth species, Diplostomum sp. The freshwater localities ST and VV had very similar Berger-Parker dominance values ( 0.54 and 0.52 , respectively) but different dominant species, the cestode Bothriocephalus claviceps and Diplostomum sp., respectively. Considering only intestinal helminths, all eels from OL were uninfected; one species was present in VV eels, two in ST eels and six in GV eels. The diversity (SW and SI) remained similar for GV but dropped for the freshwater sites. Dominance values increased considerably at ST and VV but remained the same for GV. It was highest at the freshwater locality VV, where the only species found, Bothriocephalus claviceps, was completely dominant and reached 0.90 at ST. The dominant species for GV and VV remained the same but at sampling site ST the nematode generalist Raphidascaris acus became dominant species instead of Diplostomum sp.

Table 2. Sörensen's similarity index and Percentage similarity index (parenthesis) between the total helminth communities (above the diagonal) and the intestinal helminth communities (below the diagonal) of the localities studied.

\begin{tabular}{lllll}
\hline & OL & ST & VV & GV \\
OL & - & $0.50(54.0)$ & $0.50(41.0)$ & $0(0)$ \\
ST & $0(0)$ & - & $0.33(41.0)$ & $0(0)$ \\
VV & $0(0)$ & $0(0)$ & - & $0(0)$ \\
GV & $0(0)$ & $0(0)$ & $0(0)$ & - \\
\hline
\end{tabular}

Table 3. Sörensen's similarity index for total microparasite component communities of the localities studied.

\begin{tabular}{lllll}
\hline & OL & ST & VV & GV \\
OL & - & & & \\
ST & 0.73 & - & & \\
VV & 0.40 & 0.29 & - & \\
GV & 0.55 & 0.75 & 0.57 & - \\
\hline
\end{tabular}

Table 4. The diversity characteristics of the total and intestinal helminth component community of eels from Icelandic waters.

\begin{tabular}{lllll}
\hline & \multicolumn{4}{c}{ Locality } \\
\cline { 2 - 5 } & $\mathrm{VV}$ & $\mathrm{ST}$ & $\mathrm{OL}$ & $\mathrm{GV}$ \\
\hline Total component community & & & & \\
Number of eels & 30 & 30 & 15 & 20 \\
Number of species & 3 & 3 & 1 & 7 \\
Shannon-Wiener index & 0.89 & 0.84 & 0 & 0.13 \\
Simpson index & 2.25 & 2.15 & 1.00 & 1.05 \\
S-W evenness & 0.81 & 0.77 & 0 & 0.06 \\
Berger-Parker dominance & 0.52 & 0.54 & 1.00 & 0.98 \\
Dominant species & $B c$ & $D s p$ & $D s p$ & $D i$ \\
Intestinal component community & & & \\
Number of species & 1 & 2 & 0 & 6 \\
Shannon-Wiener index & 0.00 & 0.33 & 0 & 0.12 \\
SW evenness & 0.00 & 0.30 & 0 & 0.07 \\
Simpson index & 1.00 & 1.23 & 1.00 & 1.04 \\
Berger-Parker dominance & 1.00 & 0.90 & - & 0.98 \\
Dominant species & $B c$ & $R a$ & - & $D i$ \\
\hline
\end{tabular}

Bc-Bothriocephalus claviceps; Dsp - Diplostomum sp.; Di-Deropristis inflata; $R a-$ Raphidascaris acus.

Table 5. Testing of statistical difference between the total component communities diversity indices of the localities studied.

\begin{tabular}{llll}
\hline & VV & ST & OL \\
VV & - & - & - \\
ST & NS & - & - \\
OL & $* * *$ & $* * *$ & - \\
GV & $* * *$ & $* * *$ & NS \\
\hline
\end{tabular}

*** $\mathrm{P}<0.001 ; \mathrm{NS}-$ not significant difference.

Intestinal infracommunity structure

Tables 6, 7

Prevalence of coexistent helminth species in the intestine of the eels differed markedly between localities. Considerable differences occurred comparing the ma- 
rine $(\mathrm{GV})$ and freshwater localities (OL, ST, VV). Only $5 \%$ of the marine eels were uninfected compared to 50 to $100 \%$ of the freshwater eels. The prevalence of infection also differed considerably between freshwater sampling sites. A great majority (90 to $100 \%$ ) of the freshwater eels had none or one species of intestinal helminths, few ( 0 to $10 \%$ ) were infected with two species and none had three helminth species in their intestine. A striking difference was in the mean number of helminths per eel, between freshwater and marine sites, the values being 0.00 to 1.93 in freshwater eels and 90.90 in marine eels. The mean number of species per eel was also considerably lower in the freshwater eels ( 0.0 to 0.60$)$ than the marine eels (1.85), considering all eels. This difference decreased markedly looking only at infected eels. Maximum number of species parasitizing individual eels was one at VV, two at ST and four at the marine site GV. The mean BI was low at all sampling sites; the value for the marine locality though was considerably higher than at the freshwater sites, 0.17 and 0.00 to 0.03 , respectively (all eels). Considering infected eels only, the BI for GV eels remained noticeably higher. All eels from VV and OL had either no or one species, $90 \%$ of the ST eels but $45 \%$ of the GV eels.

Table 6. Prevalence (\%) of coexistent intestinal helminth species of eels from the localities studied.

\begin{tabular}{llllr}
\hline Locality & VV & ST & OL & \multicolumn{1}{c}{ GV } \\
Number of eels examined & \multicolumn{1}{c}{10} & \multicolumn{1}{l}{30} & \multicolumn{1}{c}{15} & \multicolumn{1}{c}{20} \\
\hline 0 species & 73.3 & 50.0 & 100 & 5.0 \\
1 species & 26.7 & 40.0 & 0.0 & 40.0 \\
2 species & 0.0 & 10.0 & 0.0 & 30.0 \\
3 species & 0.0 & 0.0 & 0.0 & 15.0 \\
4 species & 0.0 & 0.0 & 0.0 & 10.0 \\
\hline
\end{tabular}

\section{DISCUSSION}

\section{The parasite community structure}

A total of 20 parasite species were observed, 4 protozoans and 16 metazoans (Table 1). All the protozoan and myxozoan species (Eimeria anguillae, Chilodonella hexasticha, Trichodina fultoni, T. jadranica, Myxidium giardi, Myxobolus kotlani, two Zschokkella spp.) and seven of the helminth species (Deropristis inflata, Plagioporus angulatus, Raphidascaris acus, Eustrongylides sp., Bothriocephalus claviceps and Proteocephalus macrocephalus) are new parasite records from Icelandic waters. Myxidium giardi, Myxobolus kotlani, E. anguillae, D. inflata, P. macrocephalus and B. claviceps are more or less strictly host specific, the others are generalists. Six species (Derogenes varicus, D. inflata, Podocotyle atomon, P. angulatus, Anisakis simplex and Hysterothylacium aduncum) are marine ones and five are freshwater species (Diplostomum sp. larva, R. acus, Eustrongylides sp. larva, P. macrocephalus and B. claviceps). Myxidium giardi, Myxobolus kotlani, one of the Zschokkella spp. and E. anguillae were found both in freshwater and marine environment. Although reported both from freshwater and marine environment (Lom and
Dyková 1992), Trichodina jadranica and T. fultoni were only found on the freshwater eels. A total lack of strict freshwater parasite species in eels from the GV area indicate no or only limited travel of these eels between fresh- and marine waters.

Myxidium giardi was found in high prevalence (20 to 93\%) at all sampling sites but Eimeria anguillae, Zschokkella spp. and Myxobolus kotlani were found on rare occasions; only one or two eels from each sampling site were infected. The prevalence of Chilodonella hexasticha, Trichodina jadranica and T. fultoni was not determined; therefore these data only confirm that these species exist on eels in the Icelandic ecosystem.

\section{Comparison between sampling sites}

The similarity of the microparasite communities between the sampling sites is fairly high, 0.29 to 0.75 (Sörensen's similarity index). Myxidium giardi was found at all localities and Myxobolus kotlani at all sites except VV. One of the Zschokkella spp. was found at both ST and OL, the other at VV and GV. Considering the similarity indices, the microparasite fauna seems to be similar both in/on freshwater and marine eels as well as in/on eels from different freshwater localities. Considerable between-sites difference occurred in the helminth composition at the freshwater sites. They all have one species in common, Diplostomum sp., the only helminth species found at more than one sampling site. Although the values of SW diversity and evenness indices, as well as dominance values, are similar in eels at sites VV and ST, the total helminth species composition is quite different. The nematode Raphidascaris acus (prevalence: $43.3 \%$ ) and the cestode Proteocephalus macrocephalus $(16.6 \%)$ are common in eels from ST but are not found in the VV eels. Similarly, the cestode Bothriocephalus claviceps (26.6\%) and the larval stages of the nematode Eustrongylides sp. (13.3\%) are quite common in VV but totally absent in ST eels. This is interesting since both sampling sites are small shallow and relatively fertile lakes, harbouring the same species of fishes, i.e. brown trout, arctic char, three-spined stickleback and eels. Differences in the composition of the fish fauna of these sites could, however, elucidate these differences to some extent. Brown trout is the dominant fish species at ST but arctic char at VV. Trout is thought to play a part in the life cycle of Raphidascaris acus, both as a final host and an intermediate or a paratenic host (Moravec 1994). The existence of this helminth species in ST eels could be partly due to how common brown trout is in the lake. Moravec (1985) reported that $B$. claviceps was more frequently found in smaller eels due to differences in their diet with size. The eels from VV were considerably smaller than those from ST. Stefánsson (2000) studied the diet of eels in VV and found the tendency for smaller eels to eat proportionally more of small crustaceans, which are vital in the life cycle of B. claviceps (see Moravec 1985). Information on the invertebrate fauna of the lakes is however 
Table 7. The diversity characteristics of the intestinal infracommunity of helminths from Icelandic waters (helminths in stomach included) and several other freshwater and saline localities in Europe.

\begin{tabular}{|c|c|c|c|c|c|c|c|c|c|c|c|c|c|c|c|c|c|c|c|c|c|c|}
\hline \multirow{4}{*}{$\begin{array}{l}\text { Reference } \\
\text { Locality }\end{array}$} & \multicolumn{14}{|c|}{ Freshwater } & \multicolumn{8}{|c|}{ Marine or brackish } \\
\hline & \multirow{2}{*}{\multicolumn{3}{|c|}{$\frac{\text { Iceland }}{\text { Present study }}$}} & \multirow{2}{*}{\multicolumn{2}{|c|}{$\begin{array}{c}\text { UK } \\
\text { Kennedy } \\
1993 \\
\text { Kennedy } \\
1997\end{array}$}} & \multicolumn{4}{|c|}{ Germany } & \multirow{2}{*}{$\begin{array}{c}\text { Ireland } \\
\text { Kennedy and } \\
\text { Moriarty } \\
2002\end{array}$} & \multirow{2}{*}{\multicolumn{4}{|c|}{$\begin{array}{c}\text { Portugal } \\
\text { Saraiva et al.2005 }\end{array}$}} & \multirow{3}{*}{ 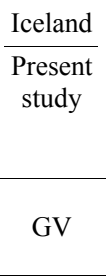 } & \multicolumn{7}{|c|}{ Italy } \\
\hline & & & & & & \multicolumn{2}{|c|}{$\begin{array}{c}\text { Sures } \\
\text { et al. } 1999\end{array}$} & \multicolumn{2}{|c|}{$\begin{array}{l}\text { Sures and } \\
\text { Streit } \\
2001\end{array}$} & & & & & & & \multicolumn{4}{|c|}{ Kennedy et.al. 1997} & \multicolumn{3}{|c|}{$\begin{array}{c}\text { Di Cave et al. } \\
2001\end{array}$} \\
\hline & VV & ST & $\mathrm{OL}$ & $\begin{array}{c}\text { Clyst } \\
1979-92 \\
\text { (min-max) }\end{array}$ & $\begin{array}{c}\text { Otter } \\
1985-96 \\
\text { (min-max) }\end{array}$ & LA & $\mathrm{RH}$ & Worms & Alb & $\begin{array}{l}\text { Shannon } \\
\text { 1983-2001 } \\
\text { (min-max) }\end{array}$ & Trovela & Covo & Este & Sousa & & Burano & Fogliano & Monaci & Caprolace & Comaccio & Figeri & Acquatina \\
\hline NO. OF EELS & 30 & 30 & 15 & $\begin{array}{c}459 \\
(27-100)\end{array}$ & $\begin{array}{c}216 \\
(10-43)\end{array}$ & 61 & 60 & 35 & 19 & $\begin{array}{c}309 \\
(11-25)\end{array}$ & 55 & 79 & 47 & 93 & 20 & 28 & 20 & 44 & 38 & 42 & 33 & 21 \\
\hline \multicolumn{23}{|c|}{ NO. OF HELMINTHS } \\
\hline $\bar{x}$ & 1.53 & 1.93 & 0 & $\begin{array}{c}1.04^{1} \\
(0-10.2)\end{array}$ & $\begin{array}{c}0.77^{1} \\
(0-7.0)\end{array}$ & 17.8 & 15.0 & 4.7 & 9.1 & $\begin{array}{c}16.85^{1} \\
(2.3-79.1)\end{array}$ & 0.95 & 0.91 & 0.72 & 2.48 & 90.90 & 10.0 & 8.4 & 9.9 & 2.6 & 45.9 & 63.2 & 10.1 \\
\hline SD & 4.68 & 3.93 & 0 & - & & 37.2 & 23.9 & 18.9 & 21.2 & - & 1.52 & 3.34 & 0.55 & 7.31 & 119.26 & 11.4 & 12.2 & 18.8 & 3.9 & 59.9 & 76.6 & 27.8 \\
\hline \multicolumn{23}{|c|}{ NO. OF HELMINTH SPP. (ALL EELS) } \\
\hline $\bar{x}$ & 0.27 & 0.60 & 0 & $\begin{array}{c}0.67^{1} \\
(0-1.44)\end{array}$ & $\begin{array}{c}0.51^{1} \\
(0-2.23)\end{array}$ & 0.6 & 0.9 & 0.3 & 1.3 & $\begin{array}{c}1.15^{1} \\
(0.7-1.7)\end{array}$ & 0.49 & 0.33 & 0.32 & 0.57 & 1.85 & 1.14 & 1.25 & 0.95 & 0.60 & 2.2 & 1.8 & 0.8 \\
\hline SD & 0.45 & 0.67 & 0 & - & - & 0.8 & 0.7 & 0.6 & 1.5 & - & 0.63 & 0.55 & 0.56 & 0.70 & 1.09 & 0.72 & 0.85 & 0.80 & 0.82 & 0.8 & 0.9 & 0.8 \\
\hline $\max$ & 1 & 2 & 0 & $\begin{array}{c}2^{1} \\
(0-4)\end{array}$ & $\begin{array}{c}2^{1} \\
(0-5)\end{array}$ & 3 & 3 & 2 & 5 & $\begin{array}{c}3^{1} \\
(1-3)\end{array}$ & 2 & 2 & 2 & 4 & 4 & 3 & 3 & 3 & 3 & 4 & 4 & 3 \\
\hline \multicolumn{23}{|c|}{ NO. OF HELMINTH SPP. (INF. EELS) } \\
\hline $\bar{x}$ & 1.00 & 1.20 & 0 & - & - & 1.4 & 1.3 & 1.3 & 2.2 & - & - & - & - & - & 1.95 & 1.28 & 1.56 & 1.39 & 1.37 & 2.2 & 1.9 & 1.2 \\
\hline $\mathrm{SD}$ & 0 & 0.41 & 0 & - & - & 0.6 & 0.5 & 0.5 & 1.3 & - & - & - & - & - & 1.03 & 0.61 & 0.63 & 0.56 & 0.59 & 0.8 & 0.9 & 0.6 \\
\hline \multicolumn{23}{|c|}{ BI (ALL EELS) } \\
\hline $\bar{x}$ & 0 & 0.03 & 0 & $\begin{array}{c}0.036^{1} \\
(0-0.158)\end{array}$ & $\begin{array}{c}0.009^{1} \\
(0-0.415)\end{array}$ & 0.06 & 0.07 & 0.02 & 0.22 & $\begin{array}{c}0.061^{1} \\
(0-0.162)\end{array}$ & 0.035 & 0.013 & 0.012 & 0.024 & 0.17 & 0.064 & 0.167 & 0.088 & 0.074 & 0.37 & 0.22 & 0.03 \\
\hline SD & 0 & 0.10 & 0 & - & - & 0.17 & 0.17 & 0.08 & 0.33 & - & 0.111 & 0.068 & 0.076 & 0.096 & 0.26 & 0.181 & 0.221 & 0.179 & 0.180 & 0.29 & 0.28 & 0.10 \\
\hline $\max$. & 0 & 0.37 & 0 & $\begin{array}{c}0.366^{1} \\
(0-0.986)\end{array}$ & $\begin{array}{c}0.346^{1} \\
(0-0.957)\end{array}$ & 0.66 & 0.67 & 0.37 & 1.02 & $\begin{array}{c}0.399^{1} \\
0-0.922\end{array}$ & 0.461 & 0.366 & 0.398 & 0.549 & 0.84 & 0.755 & 0.557 & 0.592 & 0.730 & 1.08 & 1.07 & 0.47 \\
\hline \multicolumn{23}{|l|}{ BI (INF. EELS) } \\
\hline $\bar{x}$ & 0 & 0.06 & 0 & $\begin{array}{c}0.348^{1} \\
(0-0.514)\end{array}$ & - & 0.43 & 0.4 & 0.10 & 0.38 & $\begin{array}{c}0.227^{1} \\
(0-0.635)\end{array}$ & 0.087 & 0.046 & 0.057 & 0.050 & 0.18 & 0.499 & 0.418 & 0.383 & 0.142 & 0.46 & 0.39 & 0.29 \\
\hline SD & 0 & 0.13 & 0 & - & - & 0.17 & 0.19 & 0.17 & 0.36 & - & 0.165 & 0.125 & 0.140 & 0.134 & 0.26 & 0.293 & 0.102 & 0.172 & 0.142 & 0.26 & 0.26 & 0.25 \\
\hline $\begin{array}{l}\% \text { of eels with } \\
0 \text { or } 1 \text { species }\end{array}$ & 100 & 90 & 100 & $\begin{array}{c}92^{1} \\
(61-100)\end{array}$ & $\begin{array}{c}97.1^{1} \\
(45.4-100)\end{array}$ & 85.3 & 83.4 & $95^{2}$ & $60^{2}$ & $\begin{array}{c}73^{1} \\
(36-100)\end{array}$ & 91 & 96 & 95 & 94 & 45 & 82 & 60 & 75 & 84 & 19 & 42 & 90 \\
\hline
\end{tabular}

${ }^{1}$ Long-term study; median value calculated from data given by authors. ${ }^{2}$ Values estimated from a histogram given by authors. 
scarce. A difference in the sampling time might also be an affecting factor. The complete absence of intestinal helminths at locality OL is interesting but hard to explain. The difference in the intestinal infracommunity between the marine and the freshwater sites in Iceland is considerable. The total number of helminths and the helminth species per eel is much higher in the marine eels than in the freshwater ones. This is because most of the marine eel's parasites are generalists. Many of these are frequently found in distinct fish species common in Icelandic marine waters, such as Atlantic cod Gadus morhua, saithe Pollachius virens, dab Limanda limanda and anglerfish Lophius piscatorius (Køie 1983, 1993, 2000, Eydal and Ólafsdóttir 2002-2003, Eydal et al. 2005).

\section{Comparison with other parasite communities in Europe}

The microparasite fauna observed in this study resembles the one found in similar studies on the European eel. The two strict eel specific microparasites found in our study, Myxidium giardi and Eimeria anguillae, are widespread parasites of the European eel (Copland 1981, Orecchia et al. 1987, Køie 1988, Saraiva and Chubb 1989, Benajiba et al. 1994, Molnár and Székely 1995, Sures et al. 1999, Outeiral et al. 2002, Aguilar et al. 2005, Má́llo et al. 2005) and Trichodina jadranica, T. fultoni and Myxobolus kotlani have also previously been reported from eels (Markiewicz and Migala 1980, Molnár et al. 1986, Lyholt and Buchmann 1995, Madsen et al. 2000, Aguilar et al. 2005). On the other hand, based on both measures of morphological features and sites of infection, neither of the Zschokkella species found seems to be Z. stettinensis, the only reported species in the European eel (Molnár et al. 1986). An obvious difference between our study and previous ones is the total lack of the flagellate Trypanosoma granulosum in our study, but this species has been found in most other similar studies in very high prevalence (Orecchia et al. 1987, Køie 1988, Saraiva and Chubb 1989, Mo and Sterud 1998, Sures et al. 1999, Sures and Streit 2001, Outeiral et al. 2002, Aguilar et al. 2005)

Compared to previous studies, the parasite communities of freshwater eels in Iceland are, in general, speciespoorer, less diverse and have higher dominance of a single species (Tables 8, 9; Figs. 3, 4). The median number of intestinal helminths calculated from the studies selected for comparison is four species compared to zero, one and two, respectively, for the three freshwater localities OL, VV and ST in Iceland. The richest intestinal helminth community, 12 species, was observed in Lake Esrum Denmark and the lowest (no parasites found) in 1984 in River Clyst and in 1988 in River Otter as well as locality OL in Iceland. The richness is comparable at ST and VV with Lake Balaton in Hungary, Ooigem and Kerkhove in Belgium and at Markermeer and S-Ijsselmeer in the Netherlands (Table 8, Fig. 3a).
Considering the total number of macroparasites found, Lake Esrum has the richest community, 23 species and the median values are 7 for previous studies and 1, 3 and 3, respectively, for the Icelandic localities OL, ST and VV (Table 8, Fig. 3b). Looking at diversity indices (SW and SI) the values for the Icelandic localities are considerably lower than the median value for other studies (Table 8, Fig. 3c, d). The BP dominance index and the percentage of eels with $0 / 1$ species, is noticeably higher for the Icelandic localities than in most other studies (Table 8 , Fig. 3e, f). In the previous studies, the dominant intestinal species is most often an acanthocephalan species but nematode and cestode species are, however, also quite often dominant. Digenean species are, however, rarely dominating eel parasite communities in freshwater. In Iceland the dominant species in freshwater eels is the nematode Raphidascaris acus and the cestode Bothriocephalus claviceps, both common parasites of eels in Europe and dominant in several studies (Table 8). All species found at the Icelandic localities are frequently found in other studies but many of the most prevalent ones found in previous studies, such as the monogeneans Pseudodactylogyrus anguillae and P. bini (e.g. Koie 1988, Saraiva and Chubb 1989, Mo and Sterud 1998, Borgsteede et al. 1999), the acanthocephalans Acanthocephalus anguillae, A. lucii and Pomphorhynchus laevis (e.g. Conneely and McCarthy 1986, Køie 1988, Sures et al. 1999, Kennedy and Moriarty 2002, Norton et al. 2003), the nematodes Paraquimperia tenerrima, Camallanus lacustris (e.g. Moravec 1985, Conneely and McCarthy 1986, Køie 1988, Mo and Sterud 1998, Kennedy 2001) and Anguillicola crassus (e.g. Køie 1988, Molnár et al. 1991, Kennedy et al. 1997, Sures et al. 1999) and the crustacean Ergasilus gibbus (e.g. Conneely and McCarthy 1986, Køie 1988, Borgsteede et al. 1999, Aguilar et al. 2005), are absent in this study.

Some differences emerged at the intestinal infracommunity level comparing eels from Iceland to other similar studies (Table 7). The number of helminths at localities ST and VV are much lower than observed in eels from the River Rhine and River Shannon but fairly similar to the numbers observed by Saraiva et al. (2005) in Portugal. Results from River Clyst and River Otter vary greatly between sampling years, sometimes being much higher than at ST and VV but sometimes lower, the median value being somewhat lower. Of the localities in Iceland only ST eels harbour more than one helminth species and consequently the BI exceeds zero. Including all eels, the mean BI is low at ST and comparable to most of the studies considered here. It is although to some extent lower than at Worms in River Rhine and in some years in River Clyst and River Otter. Including only infected eels, the BI at ST is lower than observed elsewhere except for the Portuguese localities, where the values are comparable (Table 7). 
Table 8. Comparison of intestinal helminth component communities between the Icelandic freshwater sampling sites and numerous freshwater localities in Europe.

\begin{tabular}{|c|c|c|c|c|c|c|c|c|c|c|}
\hline Country & Reference & Locality & $\begin{array}{c}\text { No. of } \\
\text { intest. sp. } \\
\text { (min- } \\
\max )\end{array}$ & $\begin{array}{c}\text { Total } \\
\text { no. of } \\
\text { sp. }\end{array}$ & $\begin{array}{l}\text { SW index } \\
(\min -\max )\end{array}$ & $\begin{array}{c}\mathrm{SI} 1 / \mathrm{D} \\
(\min -\max )\end{array}$ & $\begin{array}{l}\text { BP dom. } \\
(\min -\max )\end{array}$ & $\begin{array}{l}\text { Dominant } \\
\text { sp. }\end{array}$ & $\begin{array}{c}\text { No. of } \\
\text { eels } \\
(\min -\max )\end{array}$ & $\begin{array}{c}0 \text { or } 1 \mathrm{sp} . \\
(\%) \\
(\min -\max )\end{array}$ \\
\hline \multirow{3}{*}{ Iceland } & \multirow[t]{3}{*}{ Present study } & OL & 0 & 1 & 0.00 & - & & 0 & 15 & 100 \\
\hline & & $\mathrm{ST}$ & 2 & 3 & 0.33 & 1.23 & 0.90 & $R a$ & 30 & 90 \\
\hline & & VV & 1 & 3 & 0.00 & 1.00 & 1.00 & $B c$ & 30 & 100 \\
\hline \multirow{3}{*}{ Denmark } & \multirow[t]{3}{*}{ Køie $1988^{1}$} & Lake Esrum & 12 & 23 & 2.20 & 7.73 & 0.19 & $\mathrm{Da} / \mathrm{Cl}$ & 120 & nd \\
\hline & & Arresø & 6 & 11 & 1.21 & 2.31 & 0.63 & $A a$ & 30 & nd \\
\hline & & Sjælsø & 4 & 12 & 1.13 & 2.67 & 0.50 & $\mathrm{Pm}$ & & nd \\
\hline \multirow[b]{2}{*}{ Norway } & \multirow{2}{*}{$\begin{array}{l}\text { Mo and } \\
\text { Sterud } \\
1998\end{array}$} & Aarungen & 4 & 7 & - & - & - & - & 3 & - \\
\hline & & Glomma & 4 & 6 & - & - & - & - & 13 & - \\
\hline \multirow{4}{*}{ Germany } & \multirow{4}{*}{$\begin{array}{l}\text { Sures et al. } \\
1999 \\
\text { Sures and } \\
\text { Streit } 2001\end{array}$} & 'LA' & 6 & 8 & 0.35 & 1.17 & 0.92 & $\mathrm{~Pa}$ & 61 & 85.3 \\
\hline & & 'RH' & 4 & 5 & 0.41 & 1.23 & 0.90 & $\mathrm{~Pa}$ & 60 & 83.4 \\
\hline & & Worms & 4 & 6 & 0.42 & 1.23 & 0.9 & $\mathrm{~Pa}$ & 35 & 95 \\
\hline & & Alb & 6 & 8 & 1.11 & 2.12 & 0.67 & $\mathrm{~Pa}$ & 19 & 60 \\
\hline Austria & $\begin{array}{l}\text { Schabuss } \\
\text { et al. } 2005^{3}\end{array}$ & $\begin{array}{l}\text { Illmitz } \\
1994-2001 \\
\text { South } \\
1996-2001\end{array}$ & $\begin{array}{c}5^{4} \\
(2-5) \\
5^{4} \\
(2-5) \\
\end{array}$ & $*$ & $\begin{array}{c}0.88^{4} \\
(0.37-1.44) \\
0.50^{4} \\
(0.21-0.88)\end{array}$ & $\begin{array}{c}1.70^{4} \\
(1.11-4.02) \\
1.36^{4} \\
(1.06-1.72)\end{array}$ & $\begin{array}{c}0.76^{4} \\
(0.30-0.95) \\
0.85^{4} \\
(0.75-0.97)\end{array}$ & $A a / B c$ & $\begin{array}{c}424 \\
(19-156) \\
296 \\
(5-180) \\
\end{array}$ & $\begin{array}{c}61.5^{4} \\
(41.5-100) \\
78.3^{4} \\
(55.9-86.7) \\
\end{array}$ \\
\hline \multirow[t]{3}{*}{ UK } & \multirow{3}{*}{$\begin{array}{l}\text { Kennedy } \\
1993 \\
\text { Kennedy } \\
1997 \\
\text { Norton }^{3} \\
\text { et al. } 2003\end{array}$} & $\begin{array}{l}\text { Clyst } \\
1981-1992 \\
\text { Otter } \\
1985-1996\end{array}$ & $\begin{array}{c}3^{4} \\
(0-9) \\
4^{4} \\
(0-8)\end{array}$ & $*$ & $\begin{array}{c}0.71^{4} \\
(0-1.04) \\
1.04^{4} \\
(0-1.83)\end{array}$ & $\begin{array}{c}1.60^{4} \\
(1.00-2.67) \\
2.38^{4} \\
(1.00-5.55)\end{array}$ & $\begin{array}{c}0.74^{4} \\
(0.50-0.88) \\
0.51^{4} \\
(0.25-1)\end{array}$ & $\begin{array}{c}A c / \\
B c / P t \\
B c / P m / P t / S i\end{array}$ & $\begin{array}{c}459 \\
(27-100) \\
216 \\
(10-43)\end{array}$ & $\begin{array}{c}92^{4} \\
(61-100) \\
97.1^{4} \\
(11.4-100)\end{array}$ \\
\hline & & Test & 8 & $*$ & 1.33 & 2.72 & 0.54 & $E t$ & 50 & 38 \\
\hline & & Thames & 8 & $*$ & 1.46 & 3.45 & 0.34 & $\mathrm{Ng}$ & 32 & 44 \\
\hline \multirow{4}{*}{ Ireland } & \multirow{4}{*}{$\begin{array}{l}\text { Kennedy and } \\
\text { Moriarty } \\
2002 \\
\text { Conneely and } \\
\text { McCarthy } \\
1986^{1}\end{array}$} & $\begin{array}{l}\text { Shannon } \\
\text { 1983-2001 }\end{array}$ & $\begin{array}{c}4^{4} \\
(1-6)\end{array}$ & $*$ & $\begin{array}{c}0.12^{4} \\
(0.04-0.30)\end{array}$ & $\begin{array}{c}1.04^{4} \\
(1.01-1.15)\end{array}$ & $\begin{array}{c}0.98^{4} \\
(0.94-1)\end{array}$ & $A l$ & $\begin{array}{c}309 \\
(11-25)\end{array}$ & $\begin{array}{c}70^{4} \\
(36-100)\end{array}$ \\
\hline & & Abbert & 5 & 7 & 1.30 & 3.30 & 0.4 & $R a$ & 33 & nd \\
\hline & & Drimneen & 7 & 10 & 1.16 & 2.59 & 0.49 & $P l$ & 49 & nd \\
\hline & & Corrib & 9 & 12 & 0.52 & 1.05 & 0.89 & $S b$ & 39 & nd \\
\hline \multirow{5}{*}{ Portugal } & \multirow{4}{*}{$\begin{array}{l}\text { Saraiva et al. } \\
2005\end{array}$} & Trovela & 4 & $*$ & 1.30 & 3.39 & 0.42 & $P t$ & 55 & 91 \\
\hline & & Covo & 3 & $*$ & 0.69 & 1.83 & 0.67 & $C t$ & 79 & 96 \\
\hline & & Este & 3 & $*$ & 0.35 & 1.20 & 0.91 & $C t$ & 47 & 95 \\
\hline & & Sousa & 4 & $*$ & 1.01 & 2.44 & 0.52 & $R a$ & 93 & 94 \\
\hline & $\begin{array}{l}\text { Saraiva and } \\
\text { Chubb } 1989 \\
\end{array}$ & Este & 4 & 6 & n.d. & n.d. & n.d. & Pt? & 129 & nd \\
\hline \multirow{2}{*}{ Spain } & \multirow{2}{*}{$\begin{array}{l}\text { Aguilar } \\
\text { et al. } 2005^{1}\end{array}$} & Ulla River & 6 & 10 & 1.37 & 3.42 & 0.39 & $S i$ & 323 & nd \\
\hline & & Tea River & 7 & 10 & 1.52 & 4.15 & 0.31 & $P t$ & 200 & nd \\
\hline \multirow{3}{*}{ Poland } & \multirow[t]{3}{*}{ Seyda $1973^{1}$} & Stotczcyn & 6 & 7 & 1.28 & 2.63 & 0.57 & $A a$ & 20 & nd \\
\hline & & Trzebiez & 5 & 8 & 0.91 & 1.97 & 0.67 & $B c$ & 33 & nd \\
\hline & & Dabie & 8 & 10 & 1.38 & 2.92 & 0.53 & $A a$ & 30 & nd \\
\hline \multirow{4}{*}{ Belgium } & \multirow{4}{*}{$\begin{array}{l}\text { Schabuss } \\
\text { et al. } 1997^{2}\end{array}$} & Ooigem & 2 & $3^{6}$ & 0.12 & 1.06 & 0.97 & $P m$ & 30 & nd \\
\hline & & Kerkhove & 2 & $3^{6}$ & 0.12 & 1.05 & 0.97 & $\mathrm{Pm}$ & 16 & nd \\
\hline & & Bavikhove & 3 & $4^{6}$ & 0.88 & 2.08 & 0.63 & $A l$ & 31 & nd \\
\hline & & St. Baafs. & 3 & $4^{6}$ & 0.40 & 1.24 & 0.90 & $A a$ & 30 & nd \\
\hline Hungary & $\begin{array}{l}\text { Molnár and } \\
\text { Székely } \\
1995^{1}\end{array}$ & L. Balaton & 2 & 7 & 0.68 & 1.95 & 0.58 & $B c$ & 82 & nd \\
\hline \multirow{3}{*}{$\begin{array}{l}\text { Nether- } \\
\text { lands }\end{array}$} & \multirow{3}{*}{$\begin{array}{l}\text { Borgsteede et } \\
\text { al. } 1999^{1}\end{array}$} & N-Ijsselm. ${ }^{5}$ & 3 & 5 & 0.08 & 1.03 & 0.99 & $A c$ & 72 & nd \\
\hline & & S-Ijsselm. ${ }^{5}$ & 2 & 4 & 0.02 & 1.005 & 0.998 & $A c$ & 92 & nd \\
\hline & & Markerm. $^{5}$ & 1 & 2 & 0 & 1.00 & 1 & $A c$ & 99 & nd \\
\hline $\begin{array}{l}\text { Former } \\
\text { Czech. }\end{array}$ & $\begin{array}{l}\text { Moravec } \\
1985\end{array}$ & Lake Mácha & 7 & 11 & n.d. & n.d. & n.d. & $B c$ & 132 & nd \\
\hline
\end{tabular}

${ }^{1}$ Values calculated from data given by authors; ${ }^{2}$ Values recalculated from data given by authors, taking only intestinal helminths into count; ${ }^{3}$ Values recalculated from data given by authors using natural $\operatorname{logarithm}\left(\ln / \log _{\mathrm{e}}\right)$ instead of $\log _{2} ;{ }^{4}$ Long-term study; median value calculated from data given by authors; ${ }^{5}$ Data from two sampling times pooled; ${ }^{6}$ Not looked for ectoparasites in the study; * Only looked for intestinal helminths in the study; nd - no data. Parasite species abbreviations: Aa - Acanthocephalus anguillae, Ac - A. clavula, Al - A. lucii, Bc-Bothriocephalus claviceps, Cl-Camallanus lacustris, Ct-Cucullanus truttae, Da-Daniconema anguillae, Et - Echinorhynchus truttae, Ng-Nicolla gallica, Pa-Paratenuisentis ambiguus, Pl-Pomphorhynchus laevis, Pm-Proteocephalus macrocephalus, Pt-Paraquimperia tenerrima, Ra - Raphidascaris acus, $S b$-Sphaerostoma bramae, $\mathrm{Si}$-Spinitectus inermis. 
Table 9. Comparison of intestinal helminth component communities between the Icelandic marine sampling site and other brackish and marine localities in Europe.

\begin{tabular}{|c|c|c|c|c|c|c|c|c|c|c|}
\hline Country & Reference & $\begin{array}{l}\text { Locality } \\
\text { (Salinity) }\end{array}$ & $\begin{array}{c}\text { No. of } \\
\text { intest. sp. } \\
\text { (min-max) }\end{array}$ & $\begin{array}{c}\text { Total } \\
\text { no. of sp. }\end{array}$ & $\begin{array}{l}\text { SW } \\
\text { index }\end{array}$ & $\begin{array}{c}\mathrm{SI} \\
1 / \mathrm{D}\end{array}$ & $\begin{array}{c}\mathrm{BP} \\
\text { dominance }\end{array}$ & $\begin{array}{l}\text { Dominant } \\
\text { sp. }\end{array}$ & $\begin{array}{l}\text { No. of } \\
\text { eels }\end{array}$ & $\begin{array}{c}0 \text { or } 1 \\
\text { sp. }(\%)\end{array}$ \\
\hline Iceland & Present study & GV (33\%o) & 6 & 7 & 0.12 & 1.04 & 0.98 & $D i$ & 20 & 45 \\
\hline \multirow{4}{*}{ Denmark } & Køie & Ulf Sund (4-8\%o) & 9 & 18 & 1.15 & 2.20 & 0.64 & $D i$ & 60 & nd \\
\hline & $1988^{1}$ & Ringk. Fjord (10\%) & 4 & 10 & 1.02 & 2.31 & 0.60 & $P m$ & 24 & nd \\
\hline & & Isefjord (15-20\%o) & 11 & 19 & 0.87 & 1.93 & 0.70 & $D i$ & 80 & nd \\
\hline & & W. Kattegat (30-34\%o) & 6 & 9 & 1.16 & 2.47 & 0.59 & $D i$ & 36 & nd \\
\hline \multirow{7}{*}{ Italy } & Kennedy & Burrano (10-40\%o) & 6 & 8 & 0.97 & 1.93 & 0.71 & $D i$ & 28 & 82 \\
\hline & et al. $1997^{2}$ & Fogliano (28-48\%o) & 3 & 4 & 1.06 & 2.79 & 0.43 & $B p$ & 20 & 60 \\
\hline & & Monaci (17-39\%o) & 3 & 4 & 1.00 & 2.58 & 0.43 & $D i$ & 44 & 75 \\
\hline & & Caprolace (32-44\%o) & 2 & 3 & 0.86 & 1.97 & 0.67 & $D i$ & 38 & 84 \\
\hline & & Valle Figheri (15-35\%o) & 5 & 11 & 0.83 & 2.03 & 0.60 & $D i$ & 33 & 42 \\
\hline & Di Cave & Comacchio (23-37\%o) & 4 & 7 & 0.81 & 1.96 & 0.65 & $D i$ & 42 & 19 \\
\hline & et al. $2001^{2}$ & Acquatina $(30-42 \%$ ) & 4 & 6 & 0.08 & 1.10 & 0.95 & $B p$ & 21 & 90 \\
\hline Netherlands & $\begin{array}{l}\text { Borgsteede } \\
\text { et al. } 1999^{1}\end{array}$ & Volkerak $^{3}$ (brackish) ${ }^{4}$ & 3 & 5 & 0.65 & 2.35 & 0.58 & $A c$ & 98 & nd \\
\hline \multirow{5}{*}{ Spain } & Outeiral et al. & Aurosa $(>30 \%)$ & 13 & 18 & 1.67 & 4.36 & 0.37 & $D i$ & 477 & nd \\
\hline & $2001,2002^{1}$ & Ferrol $(>30 \%$ ) & 13 & 17 & 0.71 & 1.68 & 0.73 & $D i$ & 479 & nd \\
\hline & Maíllo et al. & Encanyissada (3-30\%o) & 3 & 6 & 0.42 & 1.26 & 0.89 & $D i$ & 141 & nd \\
\hline & $2005^{2}$ & Tancada $(8-36 \%)$ & 1 & 3 & 0 & 1.00 & 1 & $D i$ & 39 & nd \\
\hline & & Canal Vell (8-30\%o) & 3 & 5 & 0.92 & 2.24 & 0.59 & $D i$ & 36 & nd \\
\hline $\begin{array}{l}\text { France } \\
\text { (Corsica) }\end{array}$ & $\begin{array}{l}\text { Ternengo } \\
\text { et al. } 2005^{1}\end{array}$ & Urbino pond $(>30 \%$ ) & 4 & 5 & 0.38 & 1.21 & 0.91 & $D i$ & 31 & nd \\
\hline
\end{tabular}

${ }^{1}$ Values calculated from data given by authors; ${ }^{2}$ Values recalculated from data given by authors, taking only intestinal helminths into count; ${ }^{3}$ Data from two sampling times pooled; ${ }^{4}$ Salinity not given; nd - no data. Parasite species abbreviations: Ac - Acanthocephalus clavula, Bp - Bucephalus polymorphus, Di-Deropristis inflata, Pm-Proteocephalus macrocephalus.

Compared to the number of studies of freshwater eels, relatively few have dealt with parasites of eels from brackish and full salinity environment (e.g. Køie 1988, Kennedy et al. 1997, Borgsteede et al. 1999, Di Cave et al. 2001). The number of intestinal helminth species at GV (6) in Iceland is either comparable or higher (Table 9, Fig. 4a) than that observed in most of those studies (median value 4 species). Three localities stand out regarding number of intestinal helminths, i.e. the Danish localities Isefjord (11 species) and Ulf Sund (9 species) and from the estuaries in North-West Spain, Aurosa and Ferrol (Table 9), both with 13 species. Fluctuations in salinity exist at Ulf Sund (15 to 20\%o) and Isefjord (4 to $8 \%$ ) and consequently the eels from these localities harbour a number of freshwater species, unlike the eels from GV. Although salinity at Aurosa and Ferrol exceeded $30 \%$, these eels seem to travel to freshwater or low salinity areas resulting in a number of freshwater species. When the total numbers of macroparasites are compared, 7 are found at GV compared to 3 to 19 at the other localities, with a median value of 6.5 (Table 9, Fig. 4b). The diversity at the Icelandic locality $(\mathrm{GV})$ is, on the other hand, generally lower than at the other localities, with a SW value of 0.12 and SI value of 1.04 , compared to a median value at the other localities (SW: 0.87, SI: 2.03); only Acquatina in Italian waters and Tancada in Spanish waters have lower diversity (Table 8, Fig. 4c, d). This low diversity reflects GV's high BP-dominance, the digenean species Deropristis inflata being $98 \%(\mathrm{BP}=0.98)$ of all intestinal hel- minths. Comparable BP dominance figures for the other localities range from 0.37 to 1 with a median value of 0.65 (Table 8, Fig. 4e). The eel-specific trematode $D$. inflata is the dominant species at 15 of 19 localities considered here, the trematode Bucephalus polymorphus at 2 localities and the freshwater cestode Proteocephalus macrocephalus at Ulf Sund, a low-saline (4 to 8\%) locality in Danish waters (Table 9, Fig. 4f). All compared studies share one helminth species, i.e. D. inflata, which is without doubt the most common parasite of eels in saline waters. Apart from Køie's study (1988), the species composition of the GV's eels is quite different from other studies made. As in Køie's (1988) study, most of the species found are generalists which commonly parasitize many different families of fishes, such as Atlantic cod, Gadus morhua (Køie 1993, 2000, Eydal et al. 2005), which is a very common species in Icelandic and Danish waters. The differences in the aquatic fauna at these localities most likely explain these dissimilarities.

Comparing the intestinal infracommunity of GV eels to other studies (Kennedy et al. 1997, Di Cave et. al. 2001), the mean number of species is comparable. On the other hand, the Brillouin's index is much lower but the mean number of helminths per eel considerably higher (Table 7).

In summary, the parasite communities of freshwater eels in Iceland are in general species-poorer, less diverse and have higher BP dominance than other eel communities in Europe. Marine eels, on the other hand have comparable species richness, are less diverse and, 

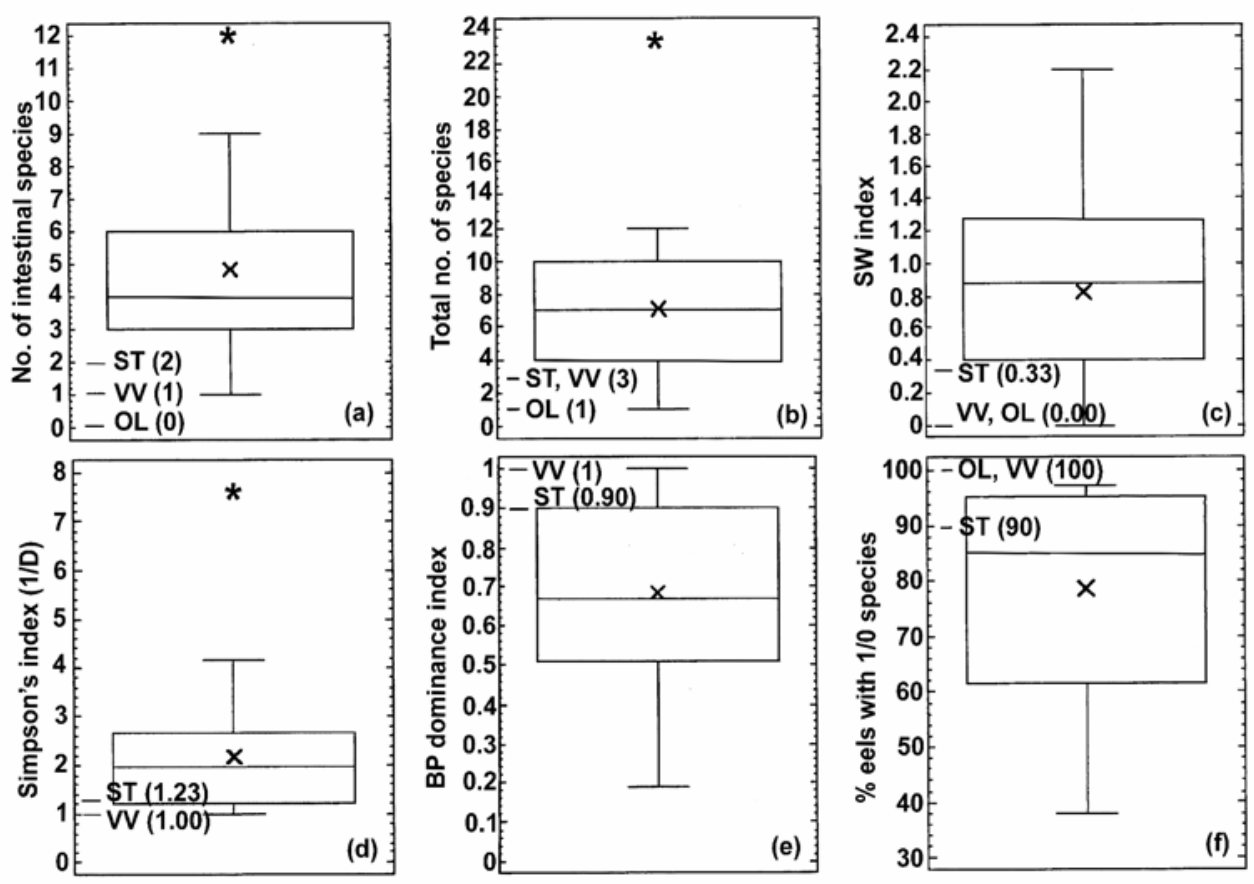

Fig. 3. Distribution of diversity characteristics from numerous European freshwater eel communities (based on data from Table 8). For comparison, values from the Icelandic sampling sites are also shown. $\mathbf{a}$ - number of intestinal species; $\mathbf{b}$ - total number of species; c - Shannon Wiener diversity index; d - Simpson's diversity index; e - Berger Parker dominance index; f - proportion (\%) of eels parasitized with one or two helminths. Note: the mean value is marked with an X.

with a high BP dominance. Similar to most previous studies, there is a total replacement of freshwater macroparasite species by marine ones in saline waters. But unlike research abroad in which species richness generally decreases with higher salinity, the marine eels in Iceland have considerably higher species richness than the freshwater ones. This difference is more due to few species in freshwater eels rather than high numbers in the marine ones.

As mentioned before, some parasite species, e.g. the flagellate Trypanosoma granulosum, the monogenean Pseudodactylogyrus spp., the swim-bladder nematode Anguillicola crassus, acanthocephalan species, the nematodes Paraquimperia tenerrima, Camallanus lacustris and the crustacean Ergasilus gibbus, which frequently parasitize freshwater eels in Europe, are not found in/on the Icelandic eels. Why is this? The biodiversity of a certain ecosystem depends on both biotic (related to living things) and abiotic factors (related to nonliving things) such as climate, minerals and light (Buchmann and Bresciani 2001), as well as on the opportunity for new species to colonize that ecosystem. The overall Icelandic freshwater vertebrate and nonparasitic invertebrate fauna is species-poor, compared to other European countries. This is clearly of great importance. Commonly parasites need an intermediate host, most frequently invertebrates, to complete their life cycle. Also, interaction between fish species is often a vital part of a parasites' life cycle. One fish species is often a paratenic or an intermediate host for a parasite that has a different fish species as a final host. The lack of suitable intermediate hosts is therefore, without doubt, one of the explanations for few parasites in the Icelandic eels. Trypanosoma granulosum, for example, uses the leeches Hemiclepsis marginata and Piscicola geometra as an intermediate host (Lom and Dyková 1992). These leeches are not a part of the invertebrate fauna of Iceland and therefore this parasite cannot be present. Regarding the acanthocephalans, the isopod Asellus aquaticus serves as an intermediate host for Acanthocephalus anguillae and A. lucii (Brown et al. 1986, Williams and Jones 1994) and the amphipods Gammarus pulex, G. fossarum and G. duebeni celticus (Irish waters) for Pomphorhynchus laevis (Brown et al. 1986, Williams and Jones 1994). None of these species inhabit the Icelandic freshwater system. As a consequence, these acanthocephalans cannot live in Icelandic freshwater. But why is the Icelandic freshwater fauna so species poor? The country's climate at its northern latitude of $64^{\circ}$ to $66^{\circ} \mathrm{N}$ is rather cold $\left(12\right.$ to $13^{\circ} \mathrm{C}$ mean temperature in July). However, because of volcanic activity in the country, many Icelandic lakes are rich in minerals, which create a good basis for the production of biotic material and fertile lakes. The northern parts of Norway and Canada and Alaska which are on similar latitudes as Iceland are, however, much richer in the vertebrate and invertebrate fauna. Many fish species which live there, e.g. northern pike, Esox lucius 

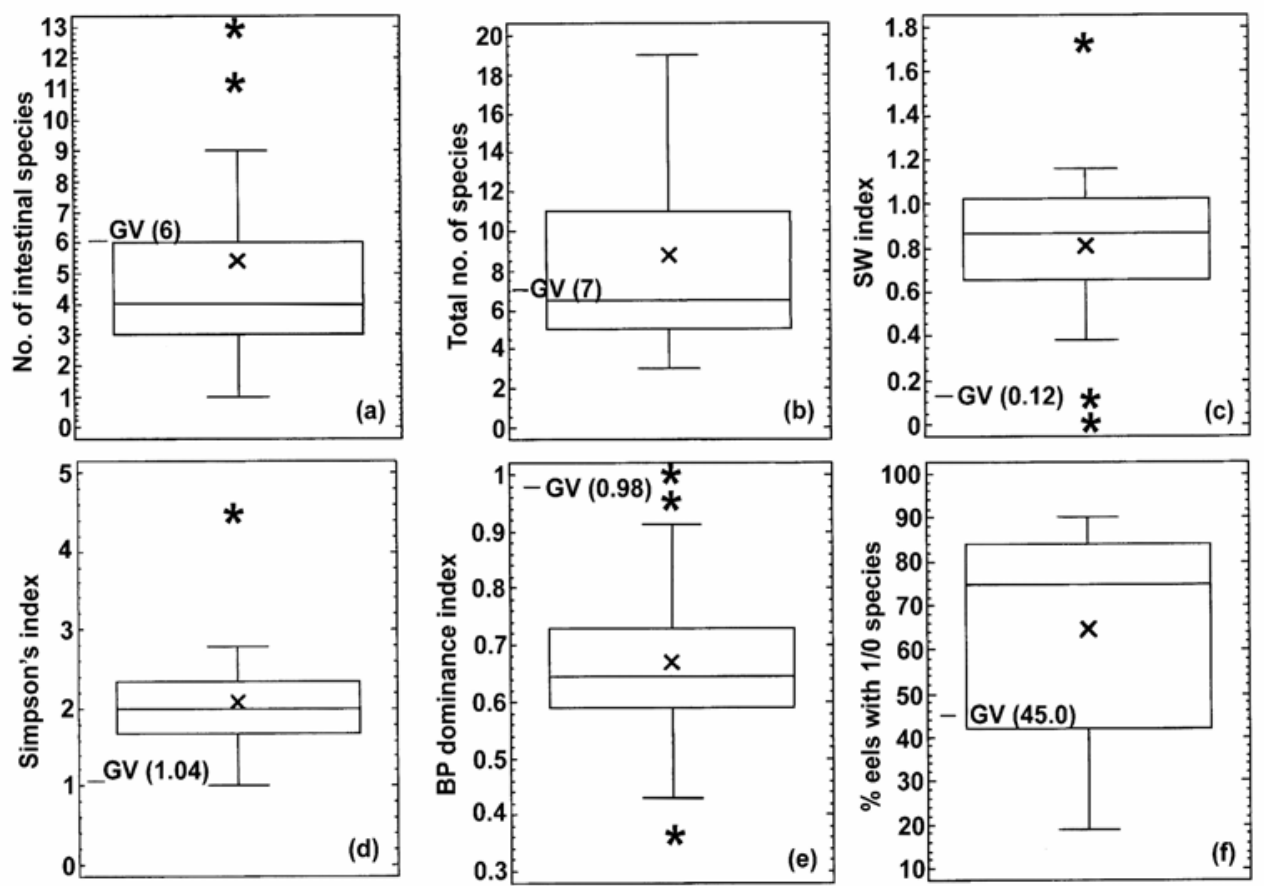

Fig. 4. Distribution of diversity characteristics from numerous European eel communities from marine and brackish localities (based on data from Table 9). For comparison, values from the Icelandic sampling site are also shown. a - number of intestinal species; b - total number of species; c - Shannon Wiener diversity index; d - Simpson's diversity index; e - Berger Parker dominance index; $\mathbf{f}$ - proportion (\%) of eels parasitized with one or two helminths. Note: the mean value is marked with an X.

(Crossman 1996), burbot, Lota lota (Cohen et al. 1990), common carp, Cyprinus carpio carpio (Welcomme 1988, Coad et al. 1995), and grayling, Thymallus thymallus in Norway (Blanc et al. 1971) and Thymallus arcticus arcticus in Canada (McClanes 1974) and Alaska (Morrow 1980) do not inhabit Iceland although abiotic factors, such as temperature, are similar in these areas. The northern position of Iceland is therefore not a sufficient explanation for its poor biodiversity. Most species of the present fauna of Iceland and the northern part of Europe and N. America have colonized these areas during the last 10 thousand years, after the last ice age. The geographical location of Iceland has, however, hampered its colonisation, whereas the recolonisation of northern European and N. American areas along rivers and coastal areas from further south has been much easier. The only fish species able to colonize Icelandic freshwater were ana- and catadromic species. The main reason for poor biodiversity in Icelandic freshwater of both invertebrates (including parasites) and vertebrates is most likely the geographical isolation and the short time span available for their colonisation. For instance, parasites like Anguillicola crassus and Pseudodactylogyrus bini, which most probably were introduced to Europe with imported eels from Asia, have due to this isolation not spread to Iceland but also because no import of live eels has been permitted. Low winter temperature of most Icelandic freshwater systems would seriously hamper a successful development of $A$. crassus (Knopf et al. 1998) except in few discrete areas affected by geothermal activity.

Many authors, studying eel parasites, have analysed their parasite community characteristics, such as diversity, evenness, species richness and species dominance. This kind of analysis is very interesting for comparison with other similar studies. When comparing data observed in different studies one must be sure that the values selected for comparison really are comparable. Regarding the analysis of eel parasite communities, authors are evidently using different logarithms for calculations of their data, natural logarithm (ln) (e.g. Aguilar et al. 2005, Saraiva et al. 2005), or logarithm with $\log$ base two $\left(\log _{2}\right)$ (e.g. Norton et al. 2003, Schabuss et al. 2005). Calculations using these two different logarithms give considerably different values and hence comparing diversity characteristics data derived from calculations with different logarithms calls for recalculations or else the comparison is meaningless. For example, the values of the SW index calculated from a certain data give values of 0.12 and 2.20 using natural logarithm but 0.05 and 0.95 using $\log _{2}$, respectively. To avoid further confusion we suggest that the more commonly used natural logarithm should be applied in future studies.

Acknowledgement. We acknowledge a grant awarded by the Icelandic Research Council. 


\section{REFERENCES}

Aguilar A., Álvarez M.F., LeIro J.M., SANMARTín M.L. 2005: Parasite populations of the European eel (Anguilla anguilla L.) in the rivers Ulla and Tea (Galicia, northwest Spain). Aquaculture 249: 85-94.

ALBERT V., JÓNSSON B., BERNATCHEZ L. 2006: Natural hybrids in Atlantic eels (Anguilla anguilla, A. rostrata): evidence for successful reproduction and fluctuating abundance in space and time. Mol. Ecol. 15: 1903-1916.

ASH L.R., ORIEL T.C. 1987: Parasites: A Guide to Laboratory Procedures and Identification. ASCP Press, Chicago, 328 pp.

BAER J.G. 1962: Cestoda. The Zoology of Iceland. Vol. 2 (12) Ejnar Munksgaard, Copenhagen and Reykjavik, 63 pp.

BenAJiBA M.H., Silan P., MARQuÉS A., BouiX G. 1994: Protozoan and metazoan parasites of the eel Anguilla anguilla L., 1758 - temporal structures of their population in a Mediterranean lagoon. Ann. Sci. Nat.-Zool. Biol. Anim. 15: 141-149.

BLAIR D. 1973: Observations and experiments on some larval trematodes of freshwater snails and fish from southern Iceland. J. Helminthol. 47: 409-414.

BlanC M., Gaudet J.L., Banarescu P., Hureau J.C. 1971: European inland water fish: a multilingual catalogue. Fishing News (Books) Ltd., London, 196 pp.

Borgsteede F.H.M., HaEnen O.L.M., DE BREE J., LisitsinA O.I. 1999: Parasitic infections of European eel (Anguilla anguilla L.) in the Netherlands. Helminthologia 36: 251-260.

BRINKMANN A. 1956: Trematoda. The Zoology of Iceland. Vol. 2 (11). Ejnar Munksgaard, Copenhagen and Reykjavik, 34 pp.

BRown A.F., CHUBB J.C., VeltCAMP C.J. 1986: A key to species of Acanthocephala parasitic in British freshwater sites. J. Fish Biol. 28: 327-334.

BUCHMANN K., BRESCIANI J. 2001: An Introduction to Parasitic Diseases of Freshwater Trout. DSR Publishers, 1 ed. Fredriksberg, $76 \mathrm{pp}$.

Bush A.O., LAFFerTy K.D., Lotz J.M., ShOSTAK A.W. 1997: Parasitology meets ecology on its own terms: Margolis et al. revisited. J. Parasitol. 83: 575-583.

BYKHOVSKAYA-PAVLOVSKAYA I.E., GUSEV A.V., DUBININA M.N., IZYUMOVA N.A., SMIRNOVA T.S., SOKOLOVSKAYA I.L., SHTEIN G.A., SHUL'MAN S.S., EPSHTEIN V.M. 1964 Key to Parasites of Freshwater Fishes of the U.S.S.R. (Pavlovskii E.N. (Ed.), Israel Program for Scientific Translators, Jerusalem, 919 pp.

COAD B.W., WASZCZUK H., LABIGNAN I. 1995: Encyclopedia of Canadian Fishes. Canadian Museum of Nature and Canadian Sportfishing Productions, Singapore, 928 pp.

COHEN D.M., INADA T., IWAMOTO T., SCIALABBA N. 1990: FAO species catalogue. Vol. 10. Gadiform fishes of the world (Order Gadiformes). An annotated and illustrated catalogue of cods, hakes, grenadiers and other gadiform fishes known to date. FAO Fish. Synop. 10 (125), 442 pp.

CONNEELY J.J., MCCARTHY T.K. 1986: Ecological factors influencing the composition of the parasite fauna of the European eel, Anguilla anguilla (L.), in Ireland. J. Fish Biol. 28: 207219.

COPLAND J.W. 1981: The occurrence and distribution of Myxidium giardi Cépède, 1906 in wild and cultured European eels, Anguilla anguilla L., in England. J. Fish Dis. 4: 231-242.

CROSSMAN E.J. 1996: Taxonomy and distribution. In: J.F. Craig (Ed.), Pike Biology and Exploration. Chapman and Hall, London, pp. 1-11.

Di Cave D., Berrilli F., De Liberato C., Orecchia P., KenNEDY C.R. 2001: Helminth communities in eels Anguilla anguilla from Adriatic coastal lagoons in Italy. J. Helminthol. 75: 7-13.
Eydal M., Helgason S., KRISTMUndSSON Á., BAMBIR S.H. 2005: Species parasitizing young Atlantic cod, Gadus morhua, in Icelandic waters. Bull. Scand.-Balt. Soc. Parasitol. 14: 55.

EYDAL M., ÓLAFSDÓTTIR D. 2002-2003: Intestinal macroparasites in anglerfish (Lophius piscatorius) from Icelandic waters. Bull. Scand. Soc. Parasitol. 12-13: 60-68.

FRANDSEN F., MALMQUIST H.J., SNORRASON S.S. 1989: Ecological parasitology of polymorphic arctic charr, Salvelinus alpinus (L.), in Thingvallavatn, Iceland. J. Fish Biol. 34: 281297.

HofFMANN G.L. 1999: Parasites of North American Freshwater Fishes, 2 ed. Cornell University Press, New York, 539 pp.

HUTCHESON K. 1970: A test for comparing diversities based on the Shannon formula. J. Theor. Biol. 29: 151-154.

KENNEDY C.R. 1993: The dynamics of intestinal helminth communities in eels Anguilla anguilla in a small stream: longterm changes in richness and structure. Parasitology 107: 7178.

KENNEDY C.R. 1997: Long-term and seasonal changes in composition and richness of intestinal helminth communities in eels Anguilla anguilla of an isolated English river. Folia Parasitol. 44: 267-273.

KENNEDY C.R. 2001: Metapopulation and community dynamics of helminth parasites of eels Anguilla anguilla in the River Exe system. Parasitology 122: 689-698.

Kennedy C.R., Di CAVE D., BerRilli F., OReCChia P. 1997: Composition and structure of helminth communities in eels Anguilla anguilla from Italian coastal lagoons. J. Helminthol. 71: 35-40.

KENNEDY C.R., MORIARTY C. 2002: Long-term stability in the richness and structure of helminth communities in eels, $\mathrm{An}$ guilla anguilla, in Lough Derg, River Shannon, Ireland. J. Helminthol. 76: 315-322.

KLEIN B.M. 1958: The "dry" silver method and its proper use. J. Protozool. 5: 99-103.

KNOPF K., WÜRTZ J., SURES B., TARASCHEWSKI H. 1998: Impact of low water temperature on the development of Anguillicola crassus in the final host Anguilla anguilla. Dis. Aquat. Org. 33: $143-149$.

KøIE M. 1983: Digenetic trematodes from Limanda limanda (L.) (Osteichthyes, Pleuronectidae) from Danish and adjacent waters, with special reference to their life cycle. Ophelia 22: 201-228

KøIE M. 1988: Parasites in European eel Anguilla anguilla (L.) from Danish freshwater, brackish and marine localities. Ophelia 29: 93-118.

KøIE M. 1993: Nematode parasites in teleosts from 0 to 1540 depth off the Faroe Islands (the North Atlantic). Ophelia 38: 217-243.

KøIE M. 2000: Metazoan parasites of teleost fishes from Atlantic waters off the Faroe Islands. Ophelia 52: 25-44.

KRISTMUNDSSON Á., RICHTER S.H. 2002-2003: Parasites of brown trout (Salmo trutta) and arctic char (Salvelinus alpinus) in two Icelandic lakes - Preliminary results. Bull. Scand. Soc. Parasitol. 12-13: 43.

LOM J., DYKOVÁ I. 1992: Protozoan Parasites of Fishes. Elsevier Science Publishers B.V., Amsterdam, 315 pp.

LYHOLT H.C.K., BUCHMANN K. 1995: Infestation with the skin parasite Trichodina jadranica Raabe, 1958 (Ciliophora: Trichodinidae) in Danish eel farms. Bull. Scand. Soc. Parasitol. 5: 97.

MADSEN H.C.K., BuChMANN K., MEllergaARD S. 2000: Trichodina sp. (Ciliophora: Peritrichida) in eel Anguilla an- 
guilla in recirculation systems in Denmark: host-parasite relations. Dis. Aquat. Org. 42: 149-152.

MAGURRAN A.E. 1988: Ecological diversity and its measurement. Croom-Helm, London, 179 pp.

Maíllo P.A., Vich M.A., SAlvadó H., MARQUÉS A., Gracia M.P. 2005: Parasites of Anguilla anguilla (L.) from three coastal lagoons of the River Ebro delta (Western Mediterranean). Acta Parasitol. 50: 156-160.

MAlmQUist H.J., SNORRASON S.S., SKúlason S. 1986: [The arctic char in Lake Thingvallavatn II. Cestode infections]. Náttúrufraedingurinn 56: 77-87. (In Icelandic.)

MARKIEWICZ F., Migala K. 1980: Trichodinid invasion (Peritricha, Urceolariidae) on young eels (Anguilla anguilla L.) grown in aquaria. Acta Hydrobiol. 22: 229-236.

MCCLANES A.J. 1974: Field Guide to Freshwater Fishes of North America. Holt, Rinehart and Winston, New York, 212 pp.

Mo T.A., STERUd E. 1998: First observations of Pseudodactylogyrus spp. and other parasites in wild eel (Anguilla anguilla L.) in Norway. Bull. Scand. Soc. Parasitol. 8: 1-5.

MOLNÁR K., LOM J., MALIK E. 1986: A skin disease of the eels caused by Myxobolus kotlani n. sp. J. Appl. Ichthyol. 2: 4248.

MOLNÁR K., SZÉKELY C. 1995: Parasitological survey of some important fish species of Lake Balaton. Parasitol. Hung. 28: 63-82.

MOLNÁR K., SZÉKELY C., BASKA F. 1991: Mass mortality of eel in Lake Balaton due to Anguillicola crassus infection. Bull. Eur. Assoc. Fish Pathol. 11: 211-212

MORAVEC F. 1985: Occurrence of endoparasitic helminths in eels (Anguilla anguilla (L.)) from the Mácha lake fishpond system, Czechoslovakia. Folia Parasitol. 32: 113-125.

MORAVEC F. 1994: Parasitic Nematodes of Freshwater Fishes of Europe. Kluwer Academic Publishers, Dordrecht, Boston, London, $473 \mathrm{pp}$.

MORROw J.E. 1980: The Freshwater Fishes of Alaska. Alaska Northwest Publishing Company, Anchorage, 248 pp.

NORTON J., LEWIS J.W., ROLLINSON D. 2003: Parasite infracommunity diversity in eels: a reflection of local component community diversity. Parasitology 127: 475-482.

Orecchia P., Bianchini M., CATAlini N., Cataudella S., PAGGI L. 1987: Parasitological study of a population of Tiber river eels (Anguilla anguilla). Parassitologia 29: 37-47.

Outeiral S., Álvarez M.F., Iglesias R., PANiagua E., SANMARTíN M.L. 2002: Non-digenean parasites of eels from estuaries in North-West Spain. Helminthologia 39: 91-97.

Outeiral S., Álvarez M.F., Paniagua E., Leiro L., SanMARTÍN M.L. 2001: Digenean parasites of the European eel from estuaries in North-West Spain. Helminthologia 38: 8592.
RICHTER S.H. 1981: [Parasites of freshwater fish i]. Veidimadurinn 107: 9-13. (In Icelandic.)

RICHTER S.H. 1982a: [Parasites of freshwater fish ii]. Veidimadurinn 108: 23-25. (In Icelandic.)

RICHTER S.H. 1982b: [Parasites of freshwater fish iii]. Veidimadurinn 109: 19-23. (In Icelandic.)

RICHTER S.H. 1982c: [Parasites of freshwater fish iv]. Veidimadurinn 110: 33-36. (In Icelandic.)

Saraiva A., ANTÃo A., CruZ C. 2005: Comparative study of parasite communities in European eel Anguilla anguilla from rivers of northern Portugal. Helminthologia 42: 99-106.

SARAIVA A., ChuBB J.C. 1989: Preliminary observations on the parasites of Anguilla anguilla (L.) from Portugal. Bull. Eur. Assoc. Fish Pathol. 9: 88.

SChabuss M., KenNedy C.R., KONECNY R., GRIllitsch B., SCHIEMER F., HERZIG A. 2005: Long-term investigation of the composition and richness of intestinal helminth communities in the stocked population of eel, Anguilla anguilla, in Neusiedler See, Austria. Parasitology 130: 185-194.

SCHABuss M., KONECNY R., BelPAiRe C., SCHIEMER F. 1997: Endoparasitic helminths of the European eel, Anguilla anguilla, from four disconnected meanders from the rivers Leie and Scheldt in western Flanders, Belgium. Folia Parasitol. 44: 12-18.

SeYDA M. 1973: Parasites of eel, Anguilla anguilla (L.), from the Szcecin firth and adjacent waters. Acta Ichthyol. Piscat. 3: $67-76$.

STEFÁNSSON S.M. 2000: [The diet of the eel (Anguilla sp.) in Lake Vifilsstadavatn]. University of Iceland, Reykjavík, 25 pp. (In Icelandic.)

STEPHENSON K. 1940: Parasitic and semiparasitic copepoda. The Zoology of Iceland. Vol. 3 (34). Ejnar Munksgaard, Copenhagen and Reykjavik, $24 \mathrm{pp}$.

SURES B., KNOPF K., WÜRTZ J., HIRT J. 1999: Richness and diversity of parasite communities in European eels Anguilla anguilla of the River Rhine, Germany, with special reference to helminth parasites. Parasitology 119: 323-330.

SURES B., STREIT B. 2001: Eel parasite diversity and intermediate host abundance in the River Rhine, Germany. Parasitology 123: $185-191$.

Ternengo S., Levron C., Desideri F., Marchand B. 2005: Parasite communities in European eels Anguilla anguilla (Pisces, Teleostei) from a Corsican coastal pond. Vie et Milieu 55: $1-6$.

WeLCOMME R.L. 1988: International introductions of inland aquatic species. FAO Fish. Tech. Pap. 294, 318 pp.

WiLliams H., JONES A. 1994: Parasitic Worms of Fish. Taylor \& Francis, London, 593 pp.

Accepted 14 December 2006 